\title{
The Production of Multimedia Courseware in Animation Teaching:
}

\author{
The Perspective of Visual Arts
}

\author{
Leilei Zhang \\ School of Fine Arts, \\ Changchun University, \\ Changchun, China \\ E-mail:zll8939095@163.com
}

\begin{abstract}
Multimedia technology is widely used today in many fields of education, its emergence and development provide more visual elements and exciting visual effects for the animation teaching courseware. This paper will propose that animation art and multimedia technology be integrated, from the perspective of visual arts, and explain the advantages and characteristics of multimedia animation teaching. This paper will also analyze and compare the different characteristics and applicable environment of the tools for multimedia courseware, and summarize the problems to which should be paid more attention. In order to better guide the design of multimedia courseware, so that readers understand the subtle integration of the arts and technologies in the animation teaching courseware.
\end{abstract}

Keywords- New Media; Visual Arts; Animation Teaching; Multimedia Courseware.

\section{INTRODUCTION}

As a new form of visual arts, animation has been demonstrated its amazing charm in the world. Although China once had brilliant Chinese Animation School and a very broad market prospect, but insufficient talents have seriously hindered the development of China's animation, which makes the animation education aroused of more and more attention.[1] The emergence of multimedia technology injects fresh blood into the animation teaching, to solve many of the problems in modern art teaching, and promote animation education into a new era.

\section{PERFECT COMBINATION OF THE VISUAL ARTS AND MULTIMEDIA TECHNOLOGY}

As a comprehensive visual art, animation combines painting, modelling, film, literature, performing and other art forms. Animation teaching is also required to reflect fully the characteristics of the visual arts, and animation teaching in support of multimedia technology is the perfect combination of technology and art. Multimedia technology being used in animation teaching is not only the development trend in the field of art education, but also the inevitable result of deepening animation education and succes sive technology innovation.

Courseware is not only an important tool for animation teaching and training, but also one of the principal means of teaching animation. In the different operating environment, courseware can be divided into stand-alone type and network type. With the support of a multimedia computer, multimedia courseware will integrate with literary letter, graphics, images, animation, sound, video and other media information, which will bring rich expression. With the development of network technology, teaching resources including multimedia courseware could be shared around the world. Multimedia courseware being used in teaching, improve the performance of teaching and interaction, and fully optimize the teaching contents, teaching methods and teaching process, greatly improve the teaching effects.

The advantages of multimedia courseware consistent with the visual requirements of animation teaching.[2] The learning environment provided by the network courseware reflects the fast, sharing and interactive features more required in the animation education. The wide application of multimedia technologies in animation teaching not only enrich the visual elements and performing language of the courseware, but also enhance greatly the teaching effectiveness, which bring a new vitality into animation teaching.

The advantages of multimedia courseware in animation mainly include:

\section{A. Various information enhance the efficiency of classroom teaching}

Traditional classroom teaching, the dissemination of knowledge mainly depend on the teacher's oral teaching and writing on the blackboard, this mode of information's transmission is not only slower and lack of image sense, but also very unsuitable for the characteristics and requirements of animation teaching, which has been limiting the amount of information in the classroom greatly. However, multimedia courseware make full use of the images, animation, audio, video and other diverse materials, impart richer information to students within the same time, that accomplish better teaching results and higher efficiency in the clas sroom.

\section{B. Rich visual expression to enhance knowledge acquisition and storage}

Multimedia courseware has a richer visual expression without time and space constraints. Through the rational use of multiple med ia resources, courseware has vivid and visualized performance of the abstract theories and concepts, simplifying and refining the complex processes 
of practical world (such as the visual principle of animation). Courseware can also simulate and reproduce what is difficult to perform in traditional teaching (such as phenomena of residual vision), to facilitate the analysis and solution of our key and difficult problems during the teaching process, which will help students understand the theory and consolidate the students' memory of knowledge.

\section{Interactive content inspire the learner's initiative cognition}

Multimedia courseware breaks the traditional way of teaching model, providing learners with ample opportunities for interaction. Rich interactive learning content lead learners to involve and think actively. The courseware is not only a teaching tool for teachers, but also an excellent helper to learners.

\section{Sharing the teaching resources and expanding the scale of teaching}

Multimedia courseware can provide adequate resources and references, organize and manage a variety of resources in a hypermedia way. It can also make different types of media information in different regions compose of an organic whole, which greatly expand the limited teaching resources. The development of online courses widen the scale of animation teaching to a large extent, which not only make the learner out of time and space constraints, but also provide a practical and effective way for China's animation education.

\section{SOFTWARES FOR PRODUCING MULTIMEDIA COURSEWARES IN ANIMATION TEACHING}

There are a great many tools for producing multimedia coursewares, but many people often do not know how to choose, the following text will briefly analyze and compare each software for producing multimedia courseware. Only by understanding the characteristics and applicable environment of each tool, you will find a suitable software.

\section{A. FounderAuthor Tool}

Founder Author Tool, developed by Founder Technology Research Institute of Peking University, is a visual interactive professional tool for multimedia authoring and publishing. It is easy to use, powerful, flexible control, and has rich performing capabilities for mu ltimedia, making the novice user to grasp quickly, and the experienced users to increase production efficiency.[3]

The main advantages of Founder Author:

1) The structure and object-based page layout, similar to Microsoft PowerPoint software, are more simple and easy to master, comparing to interface operation of Macromedia Authorware software;

2) Founder Author has low requirements to teachers' computer skills, with the action editor instead of programming, especially convenient for users of non-computer professionals to learn and use;

3) The rich page-transition effects that software owns, not only beautify the courseware but also save a lot of time;
4) Software's rich interactive effect bring more convenience for teaching;

5) To multimedia files, its integrated performance is stronger than Adobe Flash software, which is only suitable for production of vector animation.

\section{B. Adobe Flash}

Adobe Flash is an excellent vector graphics and interactive multimedia software, you can achieve a highly interactive animation. The animation files created by Flash have a high speed in transmission through network, you can download while playing, to ease the anxious emotions waiting for the page viewer. And it is composed of interactive vector graphics, can freely zoom along with the user's screen size but does not affect the playback quality. In addition, it generates bright eye-catching graphics, at the same time does not make the file volume too large. Adobe Flash is mainly used in vector animation and dynamic web production and other fields, but it is not a professional multimedia courseware authoring tool.[4]

(Fig. 1 is the catalog of courseware Animation Overview made with Flash)

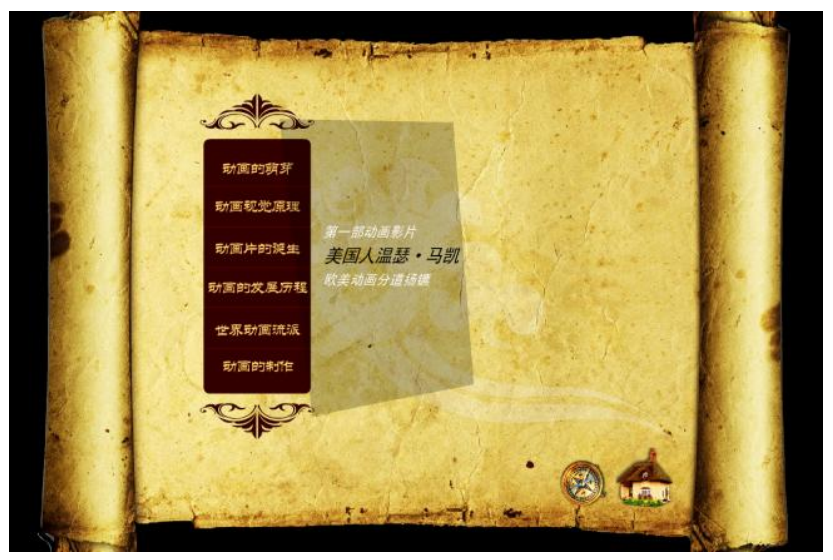

Figure 1. The Catalog of Multimedia Courseware Animation Overview

The disadvantages of Flash are mainly manifested in: Although you can create rich animation effects, Flash requires users to have high art expertises, and better computer skills. To understand and use the "time frame" in the software make the production process structural complexity, and bring a great inconvenience to modification and management. The interactive features of the document are also more complex and require expertises to use Action Script scripting language, which set the threshold to a large number of non-computer professional teachers and users. Flash has less supporting multimedia files and does not support image files. So many problems above take a long time in Flash Courseware production, although the effect is excellent, but it is suitable for the production of animation as the courseware materials (such as courseware titles, trailers, interactive buttons, etc.).

\section{FrontPage and Dreamweaver}

Microsoft FrontPage (FP) is a web design, production, publishing and management software launched by Microsoft. FrontPage has intuitive interface, easy to use, without concern for the HTML source code and mode of 
operation, be free to join all the appropriate links, graphics, animation and a variety of applications, scripts, forms, admin istration procedures, and provide a powerful wizard and template, it can also be used for Internet communication after a simple modification. But FrontPage cannot design the comple $\mathrm{x}$ interactive e xercises, complex DHTML and JavaScript pages. As easy to use, FrontPage is considered to be an excellent tool for webpage beginners. But its function cannot meet the higher requirements, so most of the high-end users take it as a substitute of the Dreamweaver that is the main competitors of Micros oft FrontPage.

Dreamweaver is a well-known website tool developed by the Macromedia company. It uses a W YSIW YG interface, is a visual Web page designing and managing tool. Dreamweave supports the latest Web technologies including HTML checking, HTML control, HTML formatting options, Home Site / BBEdit binding, visual web design, image editing, global search and replace, full FTP functionality, handling Flash and Shockwave format and dynamic HTML.[5] Dreamweaver download faster compared to FrontPage, better interaction, more beautiful and full of dynamic pages. Acting in concert with Adobe Fire works, Adobe Flash will bring infinite charm, which are called Three Web Musketeers, to design the complex courseware program and pages. But its operation is more complex, requiring teachers to have high computer skills.

\section{Macromedia Authorware}

Authorware is an icon-oriented multimedia authoring tools developed by American Macromedia company, this software make it become a reality that non-professional people develop multimedia software rapidly.[6] It doesn't require traditional computer programming, just edits some flow chart controlling the activities of program by using the icons, with collecting te xt, graphics, sound, animation, video and other multimedia project data. Its powerful functions are amazing.

(Fig. 2 is the internal page of courseware made with Authorware )

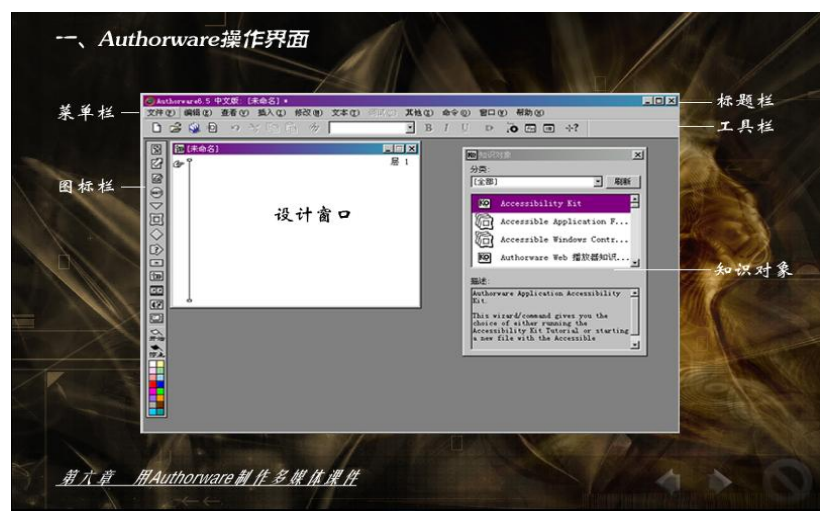

Figure 2. The Internal Page of Courseware Made with Authorware

Macromedia Authorware is widely used in the mu ltimedia courseware development of university, middle and primary school, also in multimedia CAI and so on. It has strong and abundant functions and variables, without complex programming, and the process is so orderly that the user can add texts, images, sound, animation and other media in various icons, and very easy to add buttons to interact control. However, for complicated operation and complex structure, modifications are more inconvenient, so that ordinary users are difficult to master. The capacity of producing animation is not strong, although it can open animation files made in Director and Flash, and support the interactive functions in animation. The package files binding animation are too large to transmit.

\section{E. Adobe Director}

Adobe Director can integrate a large number of media types, including pictures, sound, animation, video, database access, Internet links and other technologies into a single work, to create stunning multimedia interactive program, with a strong animation and interactivity. Using its unique engine of Shockwave 3D, we can produce spectacular three-dimensional animation effects, now a lot of multimedia teaching CD are made with Shockwave 3D. [7] But the image processing with Director is not sufficiently fine, and the file is relatively larger than Flash, which make transmission over internet is weak, learning software also takes a long time.

\section{F. Microsoft PowerPoint}

Microsoft PowerPoint is one of the important office software produced by Microsoft company, for the production of video, audio, PPT, web pages, images etc. third screen courseware.[8] It can easily enter texts, images, tables and organization charts etc., to create colorful and expressive speeches and film slides etc., suitable for teaching, reports, speeches and so on .

(Fig. 3 is the interface of courseware The Audiovisual Language of Animation made with PowerPoint)

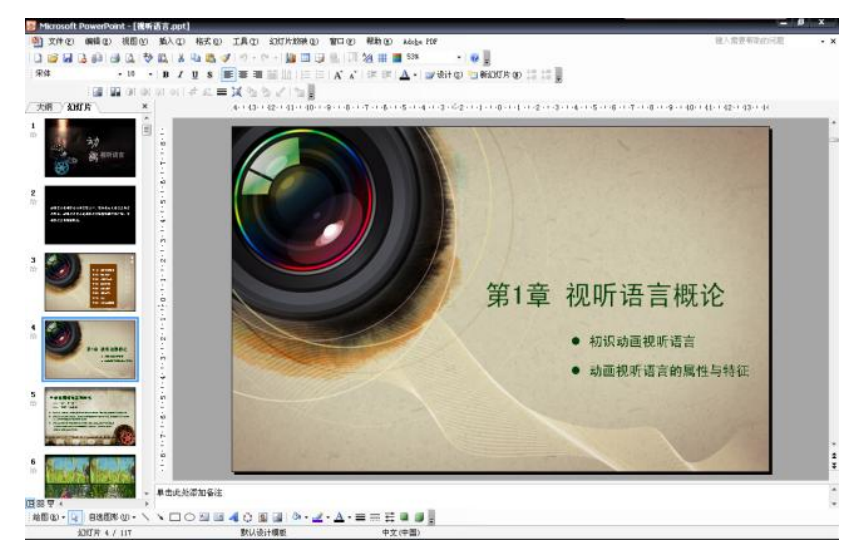

Figure 3. PowerPoint Interface

Microsoft PowerPoint cannot be called true courseware authoring tool, it should be said an electronic document tool. It is easy to learn, use less time and has a high efficiency, but the interaction is poor and only for self-presentation. Therefore, measuring with the requirements of today multimedia courseware, PowerPoint has been far from meeting the needs of our courseware production. However, we cannot deny PowerPoint's convenient and fast advantages, it is very suitable for making speeches and presentations.

\section{G. Adobe Photoshop and Premiere}


Adobe Photoshop is not a multimedia courseware authoring tool, it is a professional graphics rendering and image processing tool.[9] Using Photoshop can allow images to achieve the desired effect, we usually use Photoshop to produce page background and other materials in the Courseware. Adobe Premiere is a popular video editing software launched by Adobe company. It has an excellent editing screen and high compatibility, and can cooperate mutually with the other software introduced by Adobe Company, now widely used in commercial production and television production.[10] We use it to edit video materials to provide rich visual elements for the courseware.

In summary of the above comparison, Authorware and Director are the professional tools for producing largescale teaching CD-ROM and complicated courseware, but need a long period process to learn and produce. Flash is widely used by more people, but needs a certain basis of fine arts to get high-quality effects. FrontPage and Dreamweaver are professional web authoring tools for distance education. PowerPoint is simple and suitable for production of short-term teaching presentation. When selecting courseware tool, we should use the most simple and effective software according to specific needs, in order to achieve the best visual effect.

\section{THE PROBLEMS WE SHOULD PAY ATTENTION IN PRODUCING ANIMATION MULTIMEDIA COURSEW ARE}

We should not waste precious time on the control and debugging courseware during the actual teaching process. Therefore, the courseware should be suitable to the actual teaching environment, and provide clear teaching objectives, teaching contents, including convenient operation.

First, Courseware should be easy to install and copy to the hard disks, and be used in normal operating system. Courseware can start quickly, occupy a smaller volume as much as possible, preferably transmit and run over the network.

Second, buttons and icons should have a clear direction on the courseware interface, support mouse and avoid complex keyboard. People can easily move forward, backward and jump to the desired page, therefore we should set the interaction and transfer properly between the various parts.

Third, Courseware should run in a stable situation, to avoid a pause or crash phenomenon in the operation. If teachers perform the wrong operation, they can easily exit or restart.
Fourth, Set some good interactive functions, but should not turn courseware into a movie, with playing until the end. We should enhance the teachers' controlling capacity to the process of courseware, focusing on student feedback, so that the teaching work proceeds step by step, leaving teachers and students enough space for thinking.

\section{CONCLUSIONS}

Although the animation education began before long vigorously, animation teaching methods and means had rapid development with the promotion of new technologies and medias. The advantages of multimedia technology applied in teaching are apparent, and they had been received and supported by the students. The multimedia courseware not only improve the teachers' efficiency and reduce labor intensity, but also promote greatly the popularity and spread of animation expertise, so that more people know about animation, learn animation and love animation. Based on the principles of art teaching, we should not only take multimedia as a technology, but also turn it into a teaching art. With starting from the laws of human vision and following the principles of visual arts, we should let the students to receive professional knowledge, at the same time, enjoy imperceptibly the aesthetic visualarts.

\section{REFERENCES}

[1] LIU Zhenghua, Production of Multimedia Courseware [M], Beijing:T singhua University Press, 2001.

[2] YUAN Haidong, Multimedia Courseware Design and Production Tutorials (2nd Edition) [M], Beijing: Electronic Industry Press, 2009.

[3] GAO Ping, Founder Feiteng4.1 Layout Application Book (4th Edition) [M], Beijing: Science Press, 2013.

[4] ZHAO Zuyin, Web Design Tutorial (2nd Edition) [M], Beijing:T singhua University Press, 2005.

[5] Digital Arts Education Studio, Chinese Version Dreamweaver CS6 Basic Training Book [M], Beijing: People's Posts \& Telecom Press, 2012.

[6] ZHU Hongkang, Multimedia Authorware7.0 Courseware Tut orial [M], Beijing: People's Posts \& Telecom Press, 2006.

[7] YAN Zhihan, LI Yamei, Proficient in Director MX 2004 Multimedia Development [M], Beijing:T singhua University Press, 2005.

[8] LIi Yong, LI Wei, JIA Haitong, The Classical Book of Using PowerPoint to Make Multimedia Courseware [M], Beijing: T singhua University Press, 2014.

[9] LI Jin Ming, LI Jin Rong, Chinese Version Photoshop CS6 Self - study Book [M], Beijing: People's Posts \& Telecom Press, 2012.

[10] American Adobe Corporation, Adobe Premiere Pro CC Classical Book [M], Beijing:'People's Posts \& T elecom Press, 2015. 